\title{
Effectiveness of Cadres Training in Improving Maternal and Neonatal Health in Soreang Subdistrict
}

\author{
Merry Wijaya, ${ }^{1,2}$ Fardila Elba, ${ }^{1,2}$ Ariyati Mandiri, ${ }^{1,2}$ Wenny Friska, ${ }^{1}$ \\ Balkis Fitriani Faozi, ${ }^{1}$ Danny Hilmanto ${ }^{3}$
}

${ }^{1}$ Department of Public Health, Faculty of Medicine, Universitas Padjadjaran, Bandung, Indonesia, ${ }^{2}$ Diploma 4 Midwifery Study Program, Faculty of Medicine, Universitas Padjajaran, Bandung, Indonesia, ${ }^{3}$ Department of Child Health, Faculty of Medicine, Universitas Padjadjaran, Bandung, Indonesia

\begin{abstract}
The high maternal mortality rate (MMR) and neonatal mortality rate (NMR) are indicators of low health quality in society. Most maternal and neonatal mortality cases prevented through early detection and quick and accurate responses. Other factors that contribute to maternal and neonatal mortality are the quality of health care, the uneven distribution of health workers, and the inadequate health-supporting facilities. The government's efforts in improving fair health workers distribution and quality of healthcare services by involving integrated health service post (pos pelayanan terpadu/posyandu) cadres, as the front-liners of health care programs (especially concerning maternal and neonatal health), should be able to provide better healthcare services to the people. Hence, cadres training is crucial for improving the cadres' knowledge and skills in healthcare services. This study aims to analyze the effect of cadres training implementation on the development of cadres' knowledge and skills in giving maternal and neonatal (infant) health counseling. This study used a quasi-experimental pretest-posttest design conducted from July to November 2017. The sample consists of 32 active cadres from 12 villages in Soreang subdistrict who satisfy the inclusion criteria. Data is collected through questionnaires to measure knowledge improvement and checklists to measure cadres' skills development. The findings show that cadres training implementation can improve cadres' knowledge and skills in maternal and neonatal (infant) health counseling.
\end{abstract}

Key words: Maternal and neonatal healthcare, posyandu cadres, training

\section{Efektivitas Pelatihan Kader dalam Meningkatkan Kesehatan Ibu dan Bayi di Kecamatan Soreang}

\begin{abstract}
Abstrak
Angka kematian ibu (AKI) dan angka kematian bayi (AKB) yang tinggi menjadi indikator status kesehatan masyarakat yang rendah. Sebagian besar kasus kematian ibu dan bayi dapat dicegah melalui deteksi dini dan penanganan yang cepat dan tepat. Faktor lain yang memengaruhi kematian ibu dan bayi adalah kualitas pelayanan kesehatan, distribusi tenaga kesehatan belum merata, dan sarana pendukung pelayanan kesehatan yang belum memadai. Upaya pemerintah dalam meningkatkan pemerataan tenaga kesehatan dan pelayanan kesehatan dengan melibatkan kader pos pelayanan terpadu (posyandu) sebagai ujung tombak program kesehatan, khususnya ibu dan anak, seyogianya mampu memberikan pelayanan kesehatan yang baik kepada masyarakat. Oleh karena itu, pelatihan kader untuk meningkatkan pengetahuan dan keterampilan dalam penanganan kesehatan mutlak diperlukan. Penelitian ini bertujuan menganalisis pengaruh implementasi pelatihan kader terhadap peningkatan pengetahuan dan keterampilan dalam melakukan penyuluhan kesehatan ibu dan anak. Penelitian ini menggunakan desain quasi-experimental pretest-posttest yang dilakukan dari Juli hingga November 2017. Sampel penelitian adalah 32 kader aktif dari 12 desa di Kecamatan Soreang yang memenuhi kriteria inklusi. Pengumpulan data menggunakan kuesioner untuk menilai perubahan pengetahuan dan daftar tilik untuk mengukur perubahan keterampilan kader. Hasil penelitian menunjukkan bahwa implementasi pelatihan kader mampu meningkatkan pengetahuan dan keterampilan kader dalam melakukan penyuluhan kesehatan ibu dan anak.
\end{abstract}

Kata kunci: Kader posyandu, kesehatan ibu dan anak, pelatihan

Received: 23 August 2018; Revised: 19 October 2019; Accepted: 25 December 2019; Published: 31 December 2019

Correspondence: Dr. Merry Wijaya, M.Kes. Department of Public Health, Faculty of Medicine, Universitas Padjadjaran.

Jln. Prof. Eyckman No. 38, Bandung 40161, West Java, Indonesia. E-mail: merry_wijayao6o5@yahoo.com 


\section{Introduction}

The high maternal mortality rate (MMR) and infant mortality rate (IMR) were indicators of low health quality in a community. ${ }^{1}$ Based on the Indonesia Demography and Health Survey, the MMR in Indonesia in 2017 was 305/100,00o live births, while the IMR was 24/1,000 live births. ${ }^{2,3}$ West Java Province Health Profile reported 3,133 cases of neonatal deaths and 3,702 cases of infant deaths in the West Java province in 2016.4

The issue of maternal mortality and infant mortality rates required special attention and support from various parties to solve. One of the challenges was people's lack of knowledge concerning the importance of healthcare and prevention efforts, which included balanced nutrition, immunization, and monitoring of children's growth and development; all of which provided in integrated health service post (pos pelayanan terpadu/posyandu)..$^{3,5-7}$

The government had implemented many efforts to improve the minimum healthcare standard. However, these efforts had no positive correlation with the achievements of various programs. $.5,8$

The main challenge was finding the most appropriate way to empower people to educate them about the importance of health and a healthy lifestyle. One approach is by involving posyandu cadres as the front-liners of maternal and infant health programs. Posyandu cadres were expected to provide healthcare services as well as health education anytime anyone needed them. Hence, a cadres' training concept with the practical design was necessary to implement ideas and frameworks of comprehensive training to improve cadres' quality. ${ }^{6,9-11}$

\section{Methods}

The method implemented in this study was the quasi-experimental pretest-posttest design in one group conducted from July to November 2017. In the pretest and posttest, the cadres had about one minute to answer each question. They seated with the 1-meter distance between each of them. The pretest conducted before the cadres provided the training module. The posttest administered at the end of the training after the participants received the intervention. The intervention consisted of training, case study, and lab-skills of handling umbilical cord of newborn baby, treatment for post-natal swollen breasts of mothers, and cleansing newborn baby. Training conducted in the Soreang Community Health Center meeting room within two days in 2017.

$$
\mathrm{X} 1 \text { (pretest) } \rightarrow \text { Treatment } \rightarrow \mathrm{X} 2 \text { (posttest) }
$$

Note: $\mathrm{X} 1=$ objects before intervention, $\mathrm{X} 2=$ objects after intervention

The population for this study was all posyandu cadres in Soreang subdistrict, Bandung regency. The sample was selected through random sampling, resulting in 32 posyandu cadres who met the inclusion and exclusion criteria. They represent 32 chosen citizens association (rukun warga/RW) from 10 villages that the model area of children's health improvement program in Soreang subdistrict, Bandung regency.

The obtained data recorded and processed using SPSS Version 21. The numerical scale data presented through averages, the standard deviation, median, and range. Data analysis in this study employed paired t test to see the comparison result of pretest and posttest scores.

This study conducted after the Health Research Ethics Committee of the Faculty of Medicine of Universitas Padjadjaran issued ethical approval with letter number: 07/UN6. C1.3.2/KEPK/PN/2O17.

\section{Results}

Selected samples from each citizen association (RW) in Soreang subdistrict, Bandung regency shown in Table 1.

The evaluation of the training program was in Table 2. The table showed that the average pretest score was $71.85 \pm 6.301$, and the average posttest score was $82.98 \pm 5 \cdot 339$. The result of statistical analysis using a non-paired t test showed a great significance $(\mathrm{p}$ value $=0.000)$.

The comparison of each cadre's score showed in Figure 1.

Several clinical skills delivered in training included handling the umbilical cord of newborn baby, treatment of post-natal swollen breasts of the mother, and cleansing newborn baby. Before the treatment of providing materials and demonstrations, a pretest conducted to evaluate cadres' skills. Most of the cadres were in the 'bad' category; their skills were not as good as expected. After the treatment, each cadre asked to demonstrate their skills, and an evaluation was conducted based on the checklist for each competency. 
Table 1 Total Selected Sample from Each RW in Soreang Subdistrict, Bandung Regency

\begin{tabular}{lrrlrc}
\hline Village & RW & Number & Village & RW & Number \\
\hline Cingcin & 3 & 1 & Sadu & 10 & 1 \\
Cingcin & 9 & 1 & Sadu & 4 & 1 \\
Cingcin & 7 & 1 & Sadu & 1 & 1 \\
Cingcin & 10 & 1 & Sadu & 11 & 1 \\
Karamat Mulya & 20 & 1 & Sekarwangi & 7 & 1 \\
Karamat Mulya & 6 & 1 & Sekarwangi & 5 & 1 \\
Karamat Mulya & 2 & 1 & Sekarwangi & 7 & 1 \\
Karamat Mulya & 15 & 1 & Soreang & 12 & 1 \\
Karamat Mulya & 7 & 1 & Soreang & 20 & 1 \\
Pamekaran & 13 & 1 & Soreang & 15 & 1 \\
Pamekaran & 2 & 1 & Soreang & 22 & 1 \\
Pamekaran & 6 & 1 & Soreang & 7 & 1 \\
Panyirapan & 13 & 1 & Sukajadi & 15 & 1 \\
Panyirapan & 14 & 1 & Sukajadi & 7 & 1 \\
Parungserab & 3 & 1 & Sukanagara & 1 & 1 \\
Parungserab & 16 & 1 & Sukanagara & 4 & 1 \\
& & & Total & & 32 \\
\hline
\end{tabular}

The competency scored in categories: $\mathrm{A}=$ very good, $\mathrm{B}=$ good, $\mathrm{C}=$ sufficient, and $\mathrm{K}=$ bad. The detailed scoring and definition for each category were as follow: A (79-100)=the cadre was able to perform very well; B $(49-<79)=$ the cadre was able to perform well but still needed some refinement; C $(<49-29)=$ the cadre was unable to perform well but had the willingness to try; and $\mathrm{K}(<29)=$ the cadre was unable to perform well and had no willingness to try. Figure 2 displayed the result of the clinical skills test.

Based on the graph in Figure 2, it could be seen that the average skill scores of the three competencies were in A category (very good). The skill of handling newborn baby's umbilical cord had an average score of 95, swollen breast treatment had an average score of 82.5 , while the skill of cleansing baby had an average score of 93.7.

\section{Discussion}

Posyandu is one form of efforts carried out by, from, and with the community to empower and provide facilities for the community to obtain health services for mothers and children under five. ${ }^{12-14}$ Posyandu is one of the most wellknown forms of community-based health efforts today. ${ }^{15-17}$ The management of posyandu was chosen from and by the community at the time of the formation of posyandu. ${ }^{14}$

Posyandu cadres are community members who are appointed to work voluntarily in carrying out activities related to simple health services in posyandu. The role and function of cadres are

Table 2 Pretest and Posttest Scores Results

\begin{tabular}{lccl}
\hline \multirow{2}{*}{ Variables } & \multicolumn{2}{c}{ Treatment $(\mathbf{n = 3 1 )}$} & \multirow{2}{*}{ p Value } \\
\cline { 2 - 3 } & Pretest & Postest & \\
\hline Mean \pm Std & $71.85 \pm 6.301$ & $82.98 \pm 5.339$ & $0.000^{* *}$ \\
Median & 72.41 & 82.76 & \\
Range (min-max) & $51.72-79.31$ & $72.41-89.66$ & \\
\hline
\end{tabular}

Note: $\mathrm{p}$ value tested using a non-paired t test if the data distributed normally and the Mann-Whitney test if the data not distributed normally. Significance level based on $\mathrm{p}$ value $<0.05 .{ }^{* * *} \mathrm{p}$ value $<0.05$ (statistically significant) 


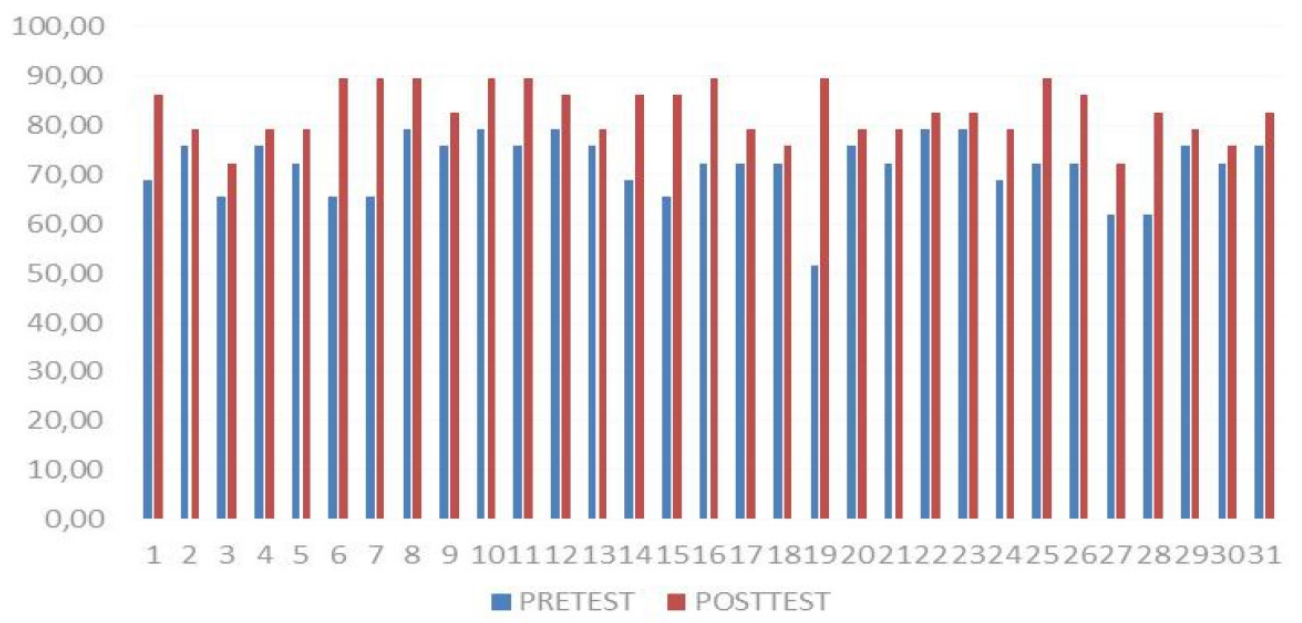

Figure 1 Comparison of Pretest and Posttest Scores

very important, starting before implementing posyandu, during, and after posyandu. ${ }^{16,17}$

A posyandu cadre is a person who, because of his skills or abilities, was appointed, selected, and or appointed to lead the development of a posyandu in a place or village. Every local male and female villager who can read and write latin letters, has free time, has the ability and is willing to work voluntarily, sincerely can be a cadre. ${ }^{18,19}$

Cadres expected to play an active role and be able to be a motivator and community instructor. Cadres expected to be able to bridge between health workers/experts and the community and help the community identify and deal with/ respond to their own health needs. ${ }^{11,13,15,17}$ The results of the posyandu cadre knowledge and skill pretest on maternal and child health fall into the poor category. They do not understand the role of cadres in posyandu activities. Knowledge obtained by cadres so far only records and

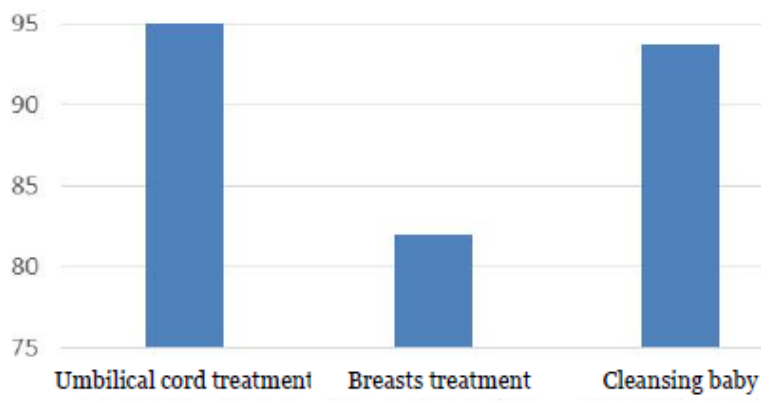

Figure 2 Result of Skill Test reports on the results of weighing under five. In the study conducted by Subagyo et al. ${ }^{13}$ that there is a relationship between the role of cadres and the motivation of mothers visiting posyandu. The active role of posyandu cadres is also highly needed to support the improvement of the level of public health, especially the health of mothers and children under five. ${ }^{19-21}$

In the results of the study, there was poor cadre knowledge and fewer skills before training. However, after the cadres were refreshed regarding knowledge and skills, there was an increase in knowledge and skills. This increase in knowledge is due to the existence of new information that is conveyed to the cadres through training, where the new information obtained is a substitute for the knowledge that has been obtained previously or is an improvement of the previous information..$^{20,22,23}$

Knowledge enhancement can be done in various ways, one of which is training activities carried out by health workers. There are several things related to cadre knowledge about assessing the growth of children under five. Know is interpreted to remember a material or science related to assessing the growth of toddlers. In this case, the cadre recalls something specific from all the material learned or stimuli that have been received. Understanding is the ability of cadres to explain correctly about assessing the growth of toddlers. ${ }^{17,22,23}$

Increased knowledge of cadres after training can occur if the material presented is easily understood by the cadres. In this training, 
the method used is the lecture and question and answer method. The cadres seemed very enthusiastic about the material presented, many of them asked about the growth of toddlers. In addition to the lecture and question and answer method, the increase in respondents' knowledge was also carried out by discussion, so that the cadres increasingly understood how to assess the growth of infants and their knowledge also increased. ${ }^{11,24}$

Components that can influence the success of training include the curriculum, instructors/ trainers, organizers, facilities used, methods, and characteristics of training participants such as age, occupation, education, and experience. The results of a study conducted by Lubis ${ }^{14}$ showed that there was a significant effect of training on cadre actions. According to Notoatmodjo, ${ }^{24}$ a person who has received training increases his knowledge and skills and can be measured by a questionnaire interview asking about the content of the material measured from study subjects or respondents in the knowledge that they want to know or adjust.

Factors that influence the performance of cadres are very complex and vary from one region to another. In addition to internal factors such as age, length of dedication, experience, social status, economic conditions, and family support; external factors such as the condition of the community and health agencies also influence the motivation and retention of cadres. Non-financial benefits are also very important for the success of a cadre program. ${ }^{25-27}$ The results of focus group discussions (not published) conducted by the writer show that the cadres feel happy and proud of the tasks carried out because they have been considered as part of the health system.

Cadres who have completed the training expected to set an example and guide other cadres in performing their duties as cadres in posyandu.

\section{Conclusion}

The findings show that cadres training implementation can improve cadres' knowledge and skills in maternal and neonatal (infant) health counseling.

\section{Conflict of Interest}

The authors declare no conflicts of interest in this study.

\section{Acknowledgment}

This study has funded by Internal Grants from Universitas Padjadjaran and was a part of the AcademicLeaderships Grant(ALG)Program1-1-6.

\section{References}

1. Ruiz JI, Nuhu K, McDaniel JT, Popoff F, Izcovich A, Criniti JM. Inequality as a powerful predictor of infant and maternal mortality around the world. PLoS One. 2015;10(10):e0140796.

2. National Population and Family Planning Board (BKKBN), Statistics Indonesia (BPS), Ministry of Health (Kemenkes), ICF. Indonesia demographic and health survey 2017. Jakarta: BKKBN, BPS, Kemenkes, ICF; 2018.

3. Kementerian Kesehatan Republik Indonesia. Profil kesehatan Indonesia tahun 2017. Jakarta: Kementerian Kesehatan Republik Indonesia; 2018.

4. Dinas Kesehatan Provinsi Jawa Barat. Profil kesehatan Provinsi Jawa Barat tahun 2016 [Internet]. Bandung: Dinas Kesehatan Provinsi Jawa Barat; 2017 [cited 2018 December 10]. Available from: http://diskes. jabarprov.go.id/dmdocuments/9738b8d468 40cc981f23c771c4187b6d.pdf.

5. Kementerian Kesehatan Republik Indonesia. Kurikulum dan modul pelatihan kader posyandu. Jakarta: Kementerian Kesehatan Republik Indonesia; 2012.

6. Green LW, Kreuter MW. Health program planning: an educational and ecological approach. $4^{\text {th }}$ Edition. New York: McGrawHill; 2005.

7. Ononokpono DN, Odimegwu CO. Determinants of maternal health care utilization in Nigeria: a multilevel approach. Pan Afr Med J. 2014;17(Suppl 1):2.

8. Alcock G, Das S, Shah More N, Hate K, More $\mathrm{S}$, Pantvaidya S, et al. Examining inequalities in uptake of maternal health care and choice of provider in underserved urban areas of Mumbai, India: a mixed methods study. BMC Pregnancy Childbirth. 2015;15:231.

9. Rosliza AM, Muhamad HJ. Knowledge, attitude and practice on antenatal care among Orang Asli women in Jempol, Negeri Sembilan. MJMHS. 2011;11(2):13-21.

10. Patel BB, Gurmeet P, Sinalkar DR, Pandya KH, 
Mahen A, Singh N. A study on knowledge and practices of antenatal care among pregnant women attending antenatal clinic at a Tertiary Care Hospital of Pune, Maharashtra. Med J DY Patil Univ. 2016;9(3):354-62.

11. Kanu JS, Tang Y, Liu Y. Assessment on the knowledge and reported practices of women on maternal and child health in rural Sierra Leone: a cross-sectional survey. PLoS One. 2014;9(8):e105936.

12. Aminuddin, Zulkifli A, Djafar N. Peningkatan peran posyandu partisipatif melalui pendampingan dan pelatihan upaya pemantauan pertumbuhan dan masalah gizi balita di Bone, Sulawesi Selatan. Kesmas Natl Public Health J. 2011;5(5):201-5.

13. Subagyo W, Mukhadiono, Wahyuningsih D. Peran kader dalam memotivasi ibu balita berkunjung ke posyandu. JKS. 2015;10(3):158-66.

14. Lubis Z. Pengetahuan dan tindakan kader posyandu dalam pemantauan pertumbuhan anak balita. KEMAS. 2015;11(3):65-73.

15. Iswarawanti DN. Kader posyandu: peranan dan tantangan pemberdayaannya dalam usaha peningkatan gizi anak di Indonesia. JMPK. 2010;13(4):169-73.

16. Lukwan. Kontribusi pengetahuan kader terhadap kinerja kader posyandu di Puskesmas Matandahi Konawe Utara. JPPPK. 2018;2(1):17-22.

17. Pusat Promosi Kesehatan, Kementerian Kesehatan Republik Indonesia. Ayo ke posyandu setiap bulan: posyandu menjaga anak dan ibu tetap sehat [Internet]. Jakarta: Kementerian Kesehatan Republik Indonesia; 2012 [cited 2018 December 12]. Available from: http://promkes.kemkes. go.id/download/jrc/files527obuku_saku_ Posyandu.pdf.

18. Kamil M. Model pendidikan dan pelatihan (konsep dan aplikasi). Cetakan ke-2. Bandung: Alfabeta; 2012.

19. Peraturan Menteri Tenaga Kerja dan
Transmigrasi Republik Indonesia Nomor 8 Tahun 2014 tentang Pedoman Penyelenggaraan Pelatihan Berbasis Kompetensi.

20. Hamza M. Training material development guide. Karlstad: Swedish Civil Contingencies Agency (MSB); 2012.

21. Bhattacharyya S, Srivastava A, Roy R, Avan BI. Factors influencing women's preference for health facility deliveries in Jharkhand state, India: a cross sectional analysis. BMC Pregnancy Childbirth. 2016;16:50.

22. Direktorat Jenderal Bina Gizi dan Kesehatan Ibu dan Anak, Kementerian Kesehatan Republik Indonesia. Pedoman penyelenggaraan manajemen terpadu balita sakit berbasis masyarakat (MTBS-M). Jakarta: Kementerian Kesehatan Republik Indonesia; 2014.

23. Rostinah, Widajanti L, Wulan LRK. Evaluasi manajemen pelatihan kader pos pelayanan terpadu (posyandu) di Puskesmas Paruga Kota Bima Provinsi Nusa Tenggara Barat. JMKI. 2015;3(3):212-21.

24. Notoatmodjo S. Promosi kesehatan dan perilaku kesehatan. Revision Edition. Jakarta: Rineka Cipta: 2012.

25. Mpembeni RNM, Killewo JZ, Leshabari MT, Massawe SN, Jahn A, Mushi D, et al. Use pattern of maternal health services and determinants of skilled care during delivery in Southern Tanzania: implications for achievement of MDG- 5 targets. BMC Pregnancy Childbirth. 2007;7:29.

26. Bulatao RA, Ross JA. Rating maternal and neonatal health services in developing countries. Bull World Health Organ. 2002;80(9):721-7.

27. Khemkratoke K, Thamsenanupap P, Noinumsai N. Community participatory training model for the conservation of medicinal plants biodiversity at Doijedee mountain tourist attraction, northeastern Thailand. Creative Educ. 2012;3(4):581-7. 